\title{
総論 スポーツエ学研究の現状と課題
}

\section{1.スポーツを取りまく環境}

\section{1 社会と経済の現状}

日本は，他の国に例を見ないほど急速に高齢社会を迎えた。 不況と言われても世界的に見れば, 依然として日本は裕福で世 界最高水準の平均寿命を誇り，人々は余㗇生活を享受している。 一方で急速な情報化の波は, 競争社会をますます助長させ, 生 活を取り巻くシステムの変化は早く, 社会からうけるストレス は強まるばかりである.このような社会環境の中で心身の健康 を保つことの重要性は，様々な意味において高まっており，こ れを実現する手段としてのスポーツがその重要性を增してくる ものと思われる.

日本経済に目を転ずるとバブル崩壊以来，閉塞状況にあり， 従来からの産業構造転換の必要性が強く言われながらもなかな か実現できないでいる. スポーツ関連産業が産業構造転換の旗 手となることが期待されていた. 現代のスポーツでは, 種目固 有のウエアで身を固め, 専用の用具を用いて専用の施設におい てプレーをするというスタイルが定着してきており, ハードウ エア(用具・施設・設備の総称)に依存する傾向が非常に強く なっている. 良い用具は, パフォーマンスを向上させるのに役 立つだけでなく, 所持していること自体に誇りと楽しみを增す 効果をもたらしている.このトレンドに乗って, ハードウエア を提供しているメーカも大きく成長してきたが，ここ数年は勢 いを失い期待を莗切っているといってよい.

現在, 競技スポーツの世界では, イベントが目白押しである. アマチュア競技の世界では, オリンピックを始めとした各種国 際大会, 国内関係では, 各種駅伝・マラソン大会·高校野球等々 があり,プロ・スポーツの世界では, 野球だけでなくサッカー・ テニス・ゴルフ・バスケットボール等々で非常に盛んであり,い ずれもテレビ放送の柱で高い梘聴率を誇っている。ここに登場 する競技者は，コマーシャリズムに乗って，収入と名誉の獲得 のために頑張っている.しかし,これらの「観るスポーツ」だ けが隆盛を誇るのは不自然で，やはり「するスポーツ」の充実

2000 年 3 月 7 日受付

* 東京工業大学 ·情報理工学研究科

₹ 152-8552 東京都目黒区大岡山 2-12-1

E-mail : ujihashi@mei.titech.ac.jp

キーワード：スポーツ工学 (Sports Engineering)，スポーツ用具

(Sports Equipment)，スポーツ産業(Sports Industry)，ハードウェア

(Hardware), 市場経済 (Economy and Market)
が, 基盤として重要であり，人々の健康や生き甲斐の源として も, 久かすことができないであろう.「するスポーツ」の促進は， インフラの整備や教育あるいはサマー・タイムの導入など政策 的にも図ることができるであろうし，スポーツ産業の振興にも つながるので, 強力な指導力が欲しいところである.

\section{2 スポーツ教育の現状}

大学を中心とした教育研究の現場においては, 従来「体育」と いう言葉が主流であった，学校体育の原点は，明治維新以来の 欧米に追いつけ追い越せの号令のもとに実行された国策に由来 する.つまり，「体育」は見劣りのした日本人の体位・体力を向 上させることが主目的であり，また挙国一致の精神を植えつけ る場としても好都合であり，規律を重視する画一的な形態がと られた.このような視点から文部省は, 専門によらずすべての 大学で体育を行うことを義務づけてきた. しかし，ようやく 10 年ほど前, 文部省は教育の大網化を打ち出し, それが実行に移 されると, 大学教育から体育の文字が少しづつ消え, あるいは スポーツという言葉に変わってきた. 同時に, 体育系学部にお いても体育の教員を育成するためだけのカリキュラムが, 実状 と適わなくなり見直しが行われるようになってきた.このよう に, 体育教育が, トップダウン式に大学から変革されようとし ている.この変化の中から新しいスポーツと科学を学んだ教育 者・研究者が育てられてくることが期待される.

「スポーツ」という言葉は，「気晴らし・娛楽」といった意味 が語源と言われているように，「体育」とは異質な概念である. 教育の現場においても, スポーツと体育では, 目的や形態が大 きく異なってくる. スポーッでは, 楽しみの追求が, 主なテー マになり，自由で個性を大切にする教育であるべきであろう. 大学は, 専門教育と研究を行う場であるから, 教養としての体 育は，本来その履修を学生の選択に委ねるべきと考える．その かわり，大学は大学人が自由に好きなスポーツに取り組むこと ができる環境を整えここれにより本来の業務効率の向上を図る べきであろう.このようなスポーツのインフラ整備は, 大学だ けの問題ではなく,すべての地域社会でも図られなければなら ない. そして, 従来学校や会社が中心であった日本の体育ある いはスポーツの拠点を地域に移すべきである.たとえば大学の スポーツインフラや教育を, その地域の社会に解放するのも良 い施策であろう。

\section{3 スポーツ産業の現状}

前述のように一生の中で, 今後も余暇時間の占める割合は増 えつづけることは確実である. そこで余暇を過ごすために使わ 
れる余暇市場の拡大に大いに期待が奇せられてきた. 表 1 は余 暇市場の推移を示したものであるが, 年間 80 ～85 兆円が現状 である.これは,バブル経済の最中に予測された数字に比べる
なり,ゴルフ関係が全体の $25 \%$ 近くを占め, 圧倒的な強みをみ せているが, 減少傾向は続いている. ウィンター・スポーツ関 係は, 大幅な滅少を強いられている. 逆に, 比較的好調なのが,

表 1 余暇市場規模の推移（「レジャー白書」・単位：億円）

\begin{tabular}{|c|c|c|c|c|c|c|}
\hline \multirow{2}{*}{ 年 } & \multirow{2}{*}{ 国民給支出 } & \multicolumn{3}{|c|}{ 余 } & \multicolumn{2}{|l|}{ 場 } \\
\hline & & スポーツ & 趣味·刢作 & 谒秦 & 钼光-行菜 & 合尌 \\
\hline 1985 & $3,215,560$ & 33,030 & 77,050 & 305,430 & 76,450 & 491,960 \\
\hline 1986 & $3,358,380$ & 34,360 & 86,960 & 320,850 & 80,920 & 523,090 \\
\hline 1987 & $3,504,790$ & 37,350 & 94,380 & 335,070 & 87,060 & 553,860 \\
\hline 1988 & $3,737,310$ & 41,170 & 104,320 & 362,510 & 98,130 & 606,130 \\
\hline 1989 & $3,990,464$ & 47,000 & 105,760 & 395,370 & 106,040 & 654,170 \\
\hline 1990 & $4,353,616$ & 51,790 & 105,580 & 448,620 & 121,710 & 727,700 \\
\hline 1991 & $4,544,865$ & 56,960 & 106,170 & 497,010 & 127,250 & 787,390 \\
\hline 1992 & $4,760,649$ & 60,050 & 106,460 & 529,550 & 124,800 & 820,860 \\
\hline 1993 & $4,797,617$ & 58,980 & 109,390 & 544,860 & 119,740 & 832,970 \\
\hline 1994 & $4,832,016$ & 57,460 & 111,570 & 560,970 & 117,250 & 847,250 \\
\hline 1995 & $4,869,214$ & 57,480 & 113,250 & 567,780 & 118,280 & 856,790 \\
\hline 1996 & $5,003,100$ & 57,000 & 119,370 & 553,470 & 121,890 & 851,730 \\
\hline 1997 & $5,078,520$ & 55,760 & 118,790 & 531,980 & 118,780 & 825,310 \\
\hline 1998 & $4,952,080$ & 53,350 & 116,210 & 517,090 & 114,420 & 801,070 \\
\hline
\end{tabular}

とかなり期待はずれではあるが, 将来有望であることには, 変 わりはない.この中のスポーツ市場は, $5 \sim 6$ 兆円で推移して いるが,ここ数年はやや減少傾向にあり，余暇市場に占める割 合も, 約 6〜 7\%で決して高いとは言えない. スポーツ市場は, さらにソフトウエアとハードウエアに分けられる，図1は，ソ フト(サービス)とハード(用品)の別にみた市場推移であるが, 1986 年以来ソフトウエアが優位を占めている. 1990 年頃の将 来予測では, 2000 年におけるスポーツ市場は, 10 兆円に達す ると言われていたが, 現在はその約半分で低迷を続けている. さらにハードウエアの中身を品目別に見てみると表2のように
釣りとアウトドア関係で, ウエア・シューズ関係も堅実である. サービスは，その質が目に見えにくいので，消費者は，必ず しも安いものに飛びっくことはないが，工業製品は，品質が一 定であるため少しでも価格の安い店で購入しようとする.そし て, 競争原理からメーカは少しでも安い製品を生み出すことに 全力を注がなければならない宿命を負っており，販売量を増や さなければ経営は成り立たない。すなわち, スポーツのハード ウエアでも大量生産・大量販売による市場規模拡大が, メーカ の基盤安定のために求められるが, 消費者によるスポーツ支出 は停滞している。この困難を克服するためには, スポーツ市場

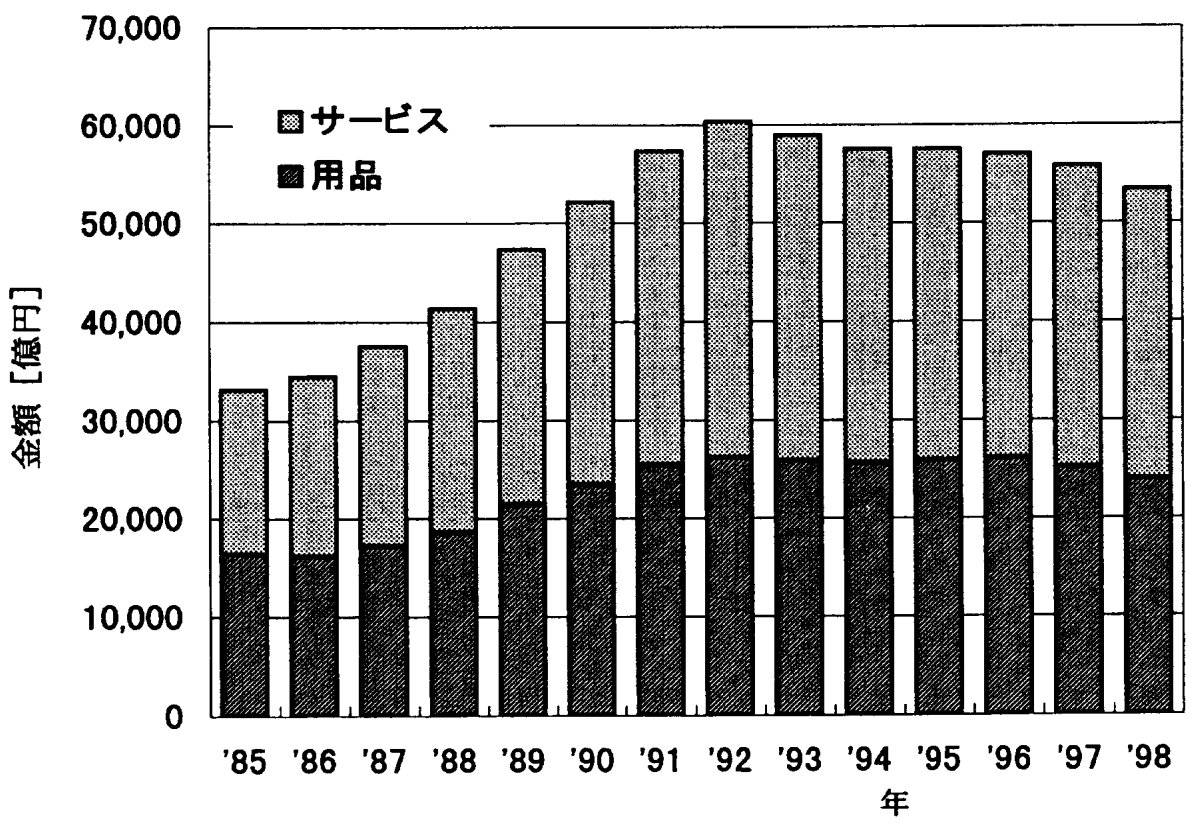

図 1 スポーツ市場規模の推移 (レジャー白書) 
表 2 品目別スポーツ市場規模の推移(「スポーツ産業年鑑 2000」・単位：億円)

\begin{tabular}{|c|c|c|c|c|c|c|c|}
\hline 品 目 & 1992年 & 1993年 & 1994年 & 1995年 & 1996年 & 1997年 & 1998年 \\
\hline コル & 6,168 & 5,824 & 5,556 & 5,570 & 5,616 & 5,409 & 4906 \\
\hline スキー・スケート & 4,039 & 3,807 & 3,480 & 3,046 & 2,508 & 1,882 & 1555 \\
\hline 为用品 & 2,399 & 2,485 & 2,580 & 2,712 & 2,867 & 2,948 & 2939 \\
\hline トレ・镂技ウェア & 2,382 & 2,477 & 2,445 & 2,433 & 2,457 & 2,377 & 2263 \\
\hline 海·水中用品 & 2,153 & 2,050 & 2,060 & 2,054 & 2,063 & 1,965 & 1848 \\
\hline 輁山·アウトドフ & 1,186 & 1,354 & 1,520 & 2,659 & 1,795 & 1,783 & 1771 \\
\hline スポーツシューズ & 1,316 & 1,365 & 1,368 & 1,394 & 1,589 & 1,625 & 1532 \\
\hline$\overline{\text { テニス }}$ & 1,282 & 1,183 & 1,123 & 1,111 & 1,029 & 941 & 854 \\
\hline 的球・ソフ ㅏㅏ & 1,141 & 1,095 & 1,059 & 1,049 & 1,113 & 1,059 & 1038 \\
\hline スノーホード & 245 & 365 & 622 & 1,058 & 1,215 & 1,326 & 1312 \\
\hline 球技末－n & 303 & 318 & 307 & 277 & 268 & 257 & 236 \\
\hline ハトミミントン & 206 & 205 & 205 & 205 & 208 & 196 & 192 \\
\hline 武道用品 & 235 & 234 & 223 & 217 & 203 & 200 & 193 \\
\hline スポーツパクグ & 151 & 160 & 152 & 145 & 167 & 160 & 141 \\
\hline 年球用品 & 148 & 143 & 144 & 144 & 141 & 134 & 134 \\
\hline その他スホーッ & 1,452 & 1,446 & 1,443 & 1,424 & 1,438 & 1,467 & 1408 \\
\hline st & 24,806 & 24,511 & 24,287 & 25,498 & 24,677 & 23,729 & 22,322 \\
\hline
\end{tabular}

拡大のための施策を行うか，あるいはより付加価值の高い製品 開発が必要であろう。

\section{2. 求められるスポーツの工学的研究}

日本では, 明治維新以来の富国強兵政策により工学教育を最 も重要視してきた。したがって，規模の大きな大学には必ず大 きな定員をもった工学部が存在し，大量に技術者の卵を産業界 に送り続けてきた，その結果として，日本の産業は発展し，い わゆる「物作り技術」は世界一の国となった。しかし，この技 術立国となった日本の中で,スポーツ産業は取り残されてきた。 現在の有力なスポーツ産業も，その前身は零細企業であり，そ の製品開発における手法は，長い間培ってきた経験に基づく職 人芸であったり，他の工業製品における製造技術の模做であっ たりした。しかし，これでは新製品の開発になかなか応用がき かないので, 物作りを支える理論・学問とその体系化が必要で ある.

日本の産業を学問的に支えてきた学会は、日本機械学会(設 立：1897 年)など多数存在し, 貴重な技術などの情報の蓄積と 体系化をおこない, 交換の場を提供してきた。しかし，これら の学会はスポーツ産業には全く関心を示してこなかった. それ では体育関係の学会はと言うと,たとえば日本体育学会(設立： 1950 年)は体育の教員を育成することを目的としている体育系 学部の研究者の集まりであり, スポーツのハードウエアの研究 や開発の専門家集団ではない.

ハードウエアの研究・開発・設計となると,やはり工学系の 専門家の手を借りなければならなくなる.しかし，スポーツや レジャーに関わる製品では，他の工業製品とは少し異なり，人 間の特性や感性に合った物作りがより強く求められる特徴を もっている.つまり，人間の情報が開発と設計の段階で取り込 まれなければ, 真に良いスポーツ・レジャー用品とはならない. したがって, その開発や研究には, 工学系の専門家だけでなく，
体育系や医学系など他の分野の専門家も必要となってくる. 従 来スポーツの用具は競技者にとって与えられるものであって, これをいかに使いこなしてパフォーマンスを上げるかが課題で あった。しかし, 現代のスポーツでは人間の能力を最大限に引 き出すには用具はどうあるべきかといった逆の発想になってき ており，人とハードが一体となったシステムとして考えられる ようになってきている．もちろん，ハードは性能ばかりが重要 ではなく，使う人に安心と楽しみを与えるような物でもなけれ ばならない。

スポーツのハードウエア研究の目的は, 性能・安全性・快適 性に集約されるであろうが，これを実現させるためには，多く の分野の研究者の参画が必要である．また，スポーツの道具で は, すべての人に最適な解か存在する性質のものではなく，基 本的に個人によって異なるものと考えるべきである。これも， スポーツのハードウエア研究における重要な視点である.

\section{3. 国内の研究動向と学会}

スポーツ用品メーカを除けば, スポーツに係わるハードウエ アに関する研究が組織的に行われていた例は，日本国内におい てはほとんどなかった。しかし，昔から専門の技術や手法をス ポーツ用具に応用した趣味の研究者は, 少なからず存在してい た. 残念ながら, そういった研究者の業績は, 受け入れるべき 適当な学協会がなかったため, 多種類の文献に分散点在し埋没 しており,利用者にとっては, 検索·発見がきわめて困難であっ た。た「スポーツ」の研究は，「遊び」や「趣味」と見られが ちで, 真剣に取り組むべき仕事あるいは業績として認知されな いといった雲囲気もあった。しかし，スポーツを取りまく環境 の変化に伴って, スポーツの研究も人間の生き甲斐や豊かな社 会建設に貢献できる大事な仕事であるとの諗識が, 持たれるよ うになってきた.この機運に乗って，スポーツのハードウエア を中心とした研究の啓蒙と推進を図り, その研究成果を業績と 
して正当に評価するとともに公表と収録を行うことを目的とし て, 1989 年に「スポーツ工学研究会」が発足し, その活動を開 始した. 定期的な研究会の開催から始まり, 翌 1990 年には, 世 界で始めての試みであったと思われる「スポーツ工学シンポジ ウム」を開催することにより情報交換の場を設けた。これは, 世 の中の支持をうけ表 3 に示すように, 現在まで 10 年間続けら れている.
ばスポーツ施設は，土木建設関係に含まれるし，設備は機械関 係に分類される場合が多い. スポーツも媦楽的な志向が強くな ると,アミューズメントあるいはレジャー分野になるであろう. たとえば，スポーツのシュミレータなどはその良い例である. スポーツ工学関係の個々の研究内容については, 文献を参考に してもらうことにし，ここでは記述を省略するが，この 10 年 間で研究内容のレベルは格段に高くなっている. 1 12)

表 3 スポーツエ学シンポジウム開催記録 (主催：日本機械学会)

\begin{tabular}{|c|c|c|c|}
\hline 開 催 年 & 場 所 & 発表稐文数 & 参加者数 \\
\hline $\begin{array}{l}1990 \\
10.25 \sim 26 \\
\end{array}$ & $\begin{array}{l}\text { 大学セミナーハウス } \\
\text { 八王子 }\end{array}$ & $\begin{array}{l}\text { 論文 } 30 \\
\text { 基期3，パネル1 }\end{array}$ & 124 \\
\hline $\begin{array}{l}1991 \\
10.30 \sim 11.1\end{array}$ & $\begin{array}{l}\text { 産業振興会馆 } \\
\text { 川㥓 }\end{array}$ & $\begin{array}{l}\text { 論文 } 31 \\
\text { 特別 } 3\end{array}$ & 188 \\
\hline $\begin{array}{l}1992 \\
10.29 \sim 30\end{array}$ & $\begin{array}{l}\text { 産業振興会馆 } \\
\text { 川崎 }\end{array}$ & $\begin{array}{l}\text { 输文 } 31 \\
\text { 特別 } 2 \text {,パネル } 2\end{array}$ & 154 \\
\hline $\begin{array}{l}1993 \\
11.10 \sim 11\end{array}$ & $\begin{array}{l}\text { きゅりあん } \\
\text { 大井町 }\end{array}$ & $\begin{array}{l}\text { 論文 } 45 \\
\text { 特別 } 2 \\
\end{array}$ & 143 \\
\hline $\begin{array}{l}1994 \\
11.10 \sim 12\end{array}$ & $\begin{array}{l}\text { 産業振興会館 } \\
\text { 川崎 }\end{array}$ & $\begin{array}{l}\text { 部文 } 46 \\
\text { 特別 3,WS2 }\end{array}$ & 157 \\
\hline $\begin{array}{l}1995 \\
10.19 \sim 21\end{array}$ & $\begin{array}{l}\text { 東京工業大学 } \\
\text { 目黒区 }\end{array}$ & $\begin{array}{l}\text { 旍文 } 46 \\
\text { 特別 } 2, \mathrm{WS} 2\end{array}$ & 170 \\
\hline $\begin{array}{l}1996 \\
10.31 \sim 11.2\end{array}$ & $\begin{array}{l}\text { コープイン } \\
\text { 京都 }\end{array}$ & $\begin{array}{l}\text { 論文 } 65 \\
\text { 特別 } 2, \mathrm{WS} 1\end{array}$ & 178 \\
\hline $\begin{array}{l}1997 \\
10.23 \sim 25\end{array}$ & $\begin{array}{l}\text { 中部大学研倍センター } \\
\text { 岐阜県・嘉那市 }\end{array}$ & $\begin{array}{l}\text { 踚文 } 50 \\
\text { 特別 } 1, \mathrm{WS} 2\end{array}$ & 140 \\
\hline $\begin{array}{l}1998 \\
10.22 \sim 24\end{array}$ & $\begin{array}{l}\text { 六甲ハウス } \\
\text { 兵庫県・芦屋市 }\end{array}$ & $\begin{array}{l}\text { 論文 } 65 \\
\text { 特別,WS }\end{array}$ & 150 \\
\hline $\begin{array}{l}1999 \\
10.27 \sim 29\end{array}$ & $\begin{array}{l}\text { 科学技術庁交流センター } \\
\text { 茨城県・つくは市 }\end{array}$ & $\begin{array}{l}\text { 論文 } 47 \\
\text { 特別企画 } 1\end{array}$ & 118 \\
\hline $\begin{array}{l}2000 \\
11.9 \sim 11\end{array}$ & $\begin{array}{l}\text { 高知会館 } \\
\text { 高知市 }\end{array}$ & 㐞集中 & - \\
\hline
\end{tabular}

学際分野らしくスポーツ工学研究会の会員の専門分野は, 機 械工学・体育学・医学・心理学など多岐にわたっている. シン ポジウムを中心として発表されてきたスポーツ工学関係の論文 数は 500 編以上に達している. 研究の内容は, 表 4 に示すとお クゴルフ・スキー・テニスの用具関係が多いが, 工学の研究は 市場规模と密接に関係している. スポーツやレジャーの範囲を 明確にすることは, 非常に困難で, 市場の規模もどこまで含め るべきかによって大きく変わり，難しいところである．たとえ

表 4 スポーツ工学シンポジウムにおける発表論文の内容別 分類 $(1990 \sim 1999)$

\begin{tabular}{|c|l|c|c|}
\hline 順 位 & 内 容 & 論文数 & 構成比 \\
\hline 1 & ヨ゙ルフ & 81 & 0.178 \\
\hline 2 & スキー & 55 & 0.121 \\
\hline 3 & テニス & 45 & 0.099 \\
\hline 4 & シューズ & 14 & 0.031 \\
\hline 5 & 自転車 & 11 & 0.024 \\
\hline
\end{tabular}

スポーツ工学研究会の発足から間もなく, スポーツ産業の育 成とこれを学問的に支援することを目的として, 通産省の眉入 れにより「日本スポーツ産業学会」が, 1990 年に発足した. こ の学会の理念は, スポーツ工学研究会の目的と一致していると ころが多かった。 日本スポーツ産業学会が 1991 年から専門分 科会制を採用したのを機に，スポーツ工学研究会は，その内の 一分科会として活動の拠点を日本スポーツ産業学会の内に置く ようになった。日本スポーツ産業学会は, 従来の体育系学会と はその理念を異にし，スポーツ産業のキーワードにより編成さ れており, 経営学·工学・歴史学・法学・教育学などきわめて 広い分野にまたがった学際学会で, 従来の縦割学会にはない横 断的な形態は注目に值する. その反面, 運営には難しい点が多 くあるが, その成長が期待される. 現在, 年に 1 回の学会大会 開催と年 2 回の機関誌「スポーツ産業学研究」の発行が, 主な 活動となっている.この機関誌には, 第 1 巻(1991 年)から第 9 巻(1999 年)まで表 5 に示すとおり合計 34 編のスポーツ工学関 係原著論文が収録されている. 現在, 7 専門分科会があり, そ れらはスポーツ工学・スポーツ医科学・スポーツマネジメント・ スポーツ指導サービス・スポーツ産業史・スポーツ法学・スポー ツ環境となっている. 
表 5 スポーツ産業学研究における発表論文の内容別分類 (第 1 巻：1991 年～第 9 巻：1999年)

\begin{tabular}{|c|l|c|}
\hline 順 位 & \multicolumn{1}{|c|}{ 内 容 } & 論 文 数 \\
\hline 1 & スポーツエ学 & 34 \\
\hline 2 & スポーツマネジメント & 12 \\
\hline \multirow{2}{*}{3} & スポーツ医科学 & 7 \\
& スポーツ産業史 & 7 \\
\hline \multirow{2}{*}{5} & スポーツ法学 & 2 \\
& スポーツ指辛サーヒス & 2 \\
\hline
\end{tabular}

スポーツの科学的研究において指導的な役割を果たしてきた のは, 1950 年に設立された日本体育学会であるが, 現在ではこ れ以外に各専門に特化した日本バイオメカニクス学会など多数 の学会がある. 最近の 10 年間の新しい傾向としては, 特定の スポーツ種目に特化し学問的には横断的な特色ある学会の誕生 である.その例を挙げると, 1991 年設立の日本スキー学会, 1987 年設立の日本ゴルフ学会, 1989 年設立の日本テニス学会などで あり，もちろんそれぞれの種目固有のハードウエアも研究対象 となっている.

\section{4 . 海外の研究動向と学会}

いわゆる日本の体育系学会に相当する国際組織として代表 的なものは, ICSSPE(International Council of Sport Science and Physical Education) - ISB (International Society of Biomechanics) を初め, ISBS (International Society of Biomechanics in Sport) • WCB (World Congress of Biomechanics)などがある。これらの 基盤とする学問分野は縦割の従来型であり，日本スポーツ産 業学会のような学問的に横断型の組織は見あたらない. 特定 のスポーツ種目の競技団体に支援された学会の発足は，日本 と同様にこの 10 年ほどの共通した傾向である.たとえば表 6 〜 8 に示すようにR\&A やUSGA にサポートされた世界ゴル フ科学会議 (World Congress of Science and Golf) や国際テニス 協会(International Tennis Federation)にサポートされた国際テ

表 6 第 1 回世界コルフ科学会議概要 (1990.7.9 13 University of St Andrews, UK)

国別内容別発表論文数

\begin{tabular}{|l|c|c|c|c|c|}
\hline Part & I & I & II & IV & Total \\
\hline USA & 9 & 5 & 8 & 3 & 25 \\
UK & 6 & 3 & 6 & 6 & 21 \\
Australia & 2 & 0 & 0 & 1 & 3 \\
Canada & 3 & 0 & 0 & 0 & 3 \\
Japan & 0 & 0 & 3 & 0 & 3 \\
Belgium & 0 & 0 & 1 & 0 & 1 \\
France & 0 & 0 & 1 & 0 & 1 \\
India & 1 & 0 & 0 & 0 & 1 \\
Korea & 0 & 0 & 0 & 1 & 1 \\
\hline Total & 21 & 8 & 19 & 11 & 59 \\
\hline
\end{tabular}

Part I : Human Factors

Part II : Performance Statistics

PartIII: Technology and Equipment

PartIV: Golf Course Management and the Environment
表 7 第 2 回世界ゴルフ科学会議概要

(1994.7.5 8 University of St Andrews, UK)

\section{国別内容別発表論文数}

\begin{tabular}{|l|r|r|r|r|}
\hline Part & \multicolumn{1}{|c|}{ I } & I & II & Total \\
\hline USA & 20 & 16 & 12 & 48 \\
UK & 5 & 5 & 13 & 23 \\
Australia & 4 & 0 & 3 & 7 \\
Canada & 3 & 0 & 1 & 4 \\
Japan & 1 & 2 & 1 & 4 \\
Sweden & 1 & 0 & 0 & 1 \\
Netherlands & 1 & 0 & 0 & 1 \\
Spain & 0 & 0 & 1 & 1 \\
India & 1 & 0 & 0 & 1 \\
Korea & 0 & 0 & 1 & 1 \\
\hline Total & 36 & 23 & 33 & 92 \\
\hline
\end{tabular}

Part I : Golfer

Part II : Equipment

PartIII : Golf Course and the Game

表 8 第 3 回世界ゴルフ科学会議概要

(1998.7.20 24 University of St Andrews, UK)

国別内容別発表論文数

\begin{tabular}{|l|c|c|c|c|}
\hline Part & I & II & III & Total \\
\hline USA & 24 & 16 & 8 & 48 \\
UK & 9 & 3 & 9 & 21 \\
Australia & 7 & 0 & 1 & 8 \\
Canada & 4 & 0 & 0 & 4 \\
Japan & 3 & 4 & 0 & 7 \\
Ireland & 1 & 0 & 0 & 1 \\
New Zealand & 1 & 0 & 0 & 1 \\
Sweden & 1 & 0 & 0 & 1 \\
Italy & 0 & 0 & 1 & 1 \\
\hline Total & 50 & 23 & 19 & 92 \\
\hline
\end{tabular}

Part I : Golfer

Part II : Equipment

PartIII : Golf Course

ニス科学会議 (International Congress on Tennis Science \& Technology)などがあり, そのカバーする学問領域は工学・医 学・経営学など学際的である.

工学的研究に焦点を絞ったスポーツ関係学会として は, 1998 年に正式発足した国際スポー工学会 ISEA (International Sports Engineering Association)がある. この学会の活動は表 9 および 10 に示すように1996年 から 2 年毎にスポーツ工学国際会議を開催する方針を とり, 正式発足後は, 年に 4 回の機関誌発行も行って おり,日本におけるスポーツ工学の活動と酷似してい る.スポーツ工学研究は,やはり豊かで余裕のある 国々が中心となっており，特にイギリス・アメリカ・ 日本が盛んである. ISEA の国際会議で発表された論 文には,トピック的にある種目などに集中する傾向は なく，多様性を示している，なお，この ISEA の第 3 回国際会議は，2000 年 6 月にシドニーにて，第 4 回 国際会議は, 2002年に日本でそれぞれ開催されること になっている. 
表 9 第 1 回スポーツ工学国際会議概要

(1996.7.2 $\sim 4$ University of Sheffield, UK)

内容別論文数（全 47 螎）

\begin{tabular}{|ll|ll|}
\hline 動作解析 & 8 編 & 生体特性 & 4 編 \\
\hline ヨ゙ルフ & 6 編 & 自転車 & 3 編 \\
\hline クリケット & 5 編 & 登山用品 & 2 編 \\
\hline ラケット・スポーツ & 5 編 & その他 & 10 編 \\
\hline トレーニング & 4 編 & & \\
\hline
\end{tabular}

国別論文数（全 47 絧）

\begin{tabular}{|ll|ll|}
\hline 連合王国 & 29 編 & カナダ & 1 編 \\
\hline アメリカ & 7 編 & ドイツ & 1 編 \\
\hline オーストリア & 3 編 & フランス & 1 編 \\
\hline 日本 & 2 編 & ポーランド & 1 編 \\
\hline オーストラリア & 1 編 & 台淩 & 1 編 \\
\hline
\end{tabular}

表 10 第 2 回スポーツ工学国際会䉿概要

(1998.7.14 $\sim 17$ University of Sheffield, UK)

内容別論文数（全 65 編）

\begin{tabular}{|c|c|c|c|}
\hline 計湘法 & 8 編 & 登山 & 4 緛 \\
\hline クリケット & 7 縞 & サッカー & 3 編 \\
\hline スキー & 7 編 & サーフェス & 3 編 \\
\hline 理作解析 & 6 楄 & テニス & 2 編 \\
\hline モデル化 & 6 編 & シュース & 2 編 \\
\hline 自転車 & 5 編 & その他 & 8 編 \\
\hline ジルフ & 5 編 & & \\
\hline
\end{tabular}

国別論文数（全 65 編）

\begin{tabular}{|lc|ll|}
\hline 連合王国 & 25 編 & スペイン & 2 編 \\
\hline 日本 & 15 編 & 台洼 & 2 編 \\
\hline フランス & 8 編 & カナダ & 1 編 \\
\hline アメリカ & 6 編 & ロシア & 1 編 \\
\hline オーストラリア & 2 編 & 南アフリカ & 1 編 \\
\hline アイルラント & 2 編 & & \\
\hline
\end{tabular}

気さえする．個人消費に占めるスポーツ支出が低迷を 続けているのが，その証拠であろう.

真に健康で豊かな社会と生活を築くためには，人々 がもっとスポーツの重要性を認識し，実施する必要が ある.そのためには, インフラ整備など教育や政策によ る「するスポーツ」の振興が図られなければならない. スポーツの工学的な研究は, 基本的に人々のスポーツ 支出が増え関連産業が大きく伸展することにより， 益々必要度が高まるものと考えられる。

\section{参考文献}

1）日本機械学会講演論文集，No.900-66(スポーツ工 学シンポジウム), (1990).

2）日本機械学会講演論文集, No.910-67(スポーツ工 学シンポジウム), (1991).

3）日本機械学会講演論文集, No.920-89(スポーツ工 学シンポジウム), (1992).

4）日本機械学会講演論文集, No.930-69(スポーツ工 学シンポジウム), (1993).

5）日本機械学会講演論文集, No.940-59(スポーツ工 学シンポジウム), (1994).

6）日本機械学会講演論文集, No.95-45(スポーツ工 学シンポジウム), (1995)。

7）日本機械学会講演論文集, No.96-20(スポーツ工 学シンポジウム), (1996).

8）日本機械学会講演論文集, No.97-34(スポーツ工 学シンポジウム), (1997).

9）日本機械学会講演論文集, No.98-31(スポーツエ 学シンポジウム), (1998).

10）日本機械学会講演論文集, No.99-41(スポーツ工 学シンポジウム), (1999).

11）日本機械学会講演論文集,No.97-10-2(スポーツ工 学シンポジウム), 1-8(1997).

12）日本機械学会論文集 $C$ 編 (小特集スポーツ工学), 64(623), 2312-2317(1998).

\section{5. 将来展望}

スポーツを支える用具・施設・設備に関する工学的研究は，ス ポーツが人々の生活の中でどのような位置付けになって行くか に大きく関係する.現在の「観るスポーツ」の隆盛に比べて,「す るスポーツ」の普及の方は, 特に若者を中心として沈滞してい るように思われる. 頂点に立つ人々のパフォーマンスは，観て いる者に感動を与えるが，これがビジネスとして捉えられ，競 技スポーツは金儲けの手段と化している感がある.

語源どおりスポーツは，実施する人のものであり，実施する 人だけが享受できる楽しみであろう．しかし現代は，生活を便 利にすることばかりが良いこととされ，身体を動かすことは無 駄であるかのように思っている人が少なくない. スポーツの大 切さを知っているのは, 残念ながら一部の年輩者だけのような

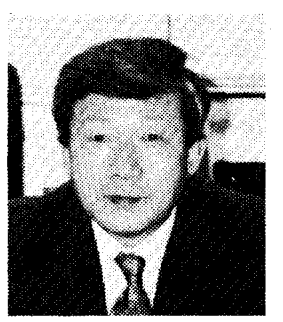

宇治橋貞幸 (うじはしささだゆき) 1971 年東京工業大学大学院修士課程修了, 1982 年工学博士. 同大学工学部機械工学 科助手, 助教授, 教授を経て 1994 年より 同大学大学院 情報理工学研究科教授, 1989 ～1990年イギリス・ストラスクライ ド大学客員教授. 研究分野は, スポーツ工 学, 衝撃工学, バイオメカニクス, 安全工学であり, シューズ の官能評価・ヘルメットの頭部保護性能・ゴルフインパクトの 解析などの研究に従事. 日本機械学会, 日本スポーツ産業学会, ISEA (International Sports Engineering Association), ISB (International Society of Biomechanics), 日本複合材料学会, 日 本材料学会, 自動車技術会, 日本バイオメニクス学会の会員. 